БУХГАЛТЕРСЬКИЙ ОБЛІК, АНА ЛІЗ ТА АУДИТ

UDC 657

DOI: https://doi.org/10.32782/2520-2200/2019-1-38

Kolumbet Olena
State University of Infrastructure and Technology
Yarmolitska Olha
State University of Infrastructure and Technology
Yarmolich Olha
State University of Infrastructure and Technology

Колумбет О.П.

кандидат економічних наук, доцент, доцент кафедри обліку і оподаткування Державного університету інфрраструктури та технологій

Ярмоліцька О.В.

кандидат економічних наук, доцент, доцент кафедри обліку і оподаткування Державного університету інфраструктури та технологій

Ярмоліч О.М. магістр

Державного університету інфраструктури та технологій

\title{
PLACE AND ROLE OF ACCOUNTS RECEIVABLE IN THE SYSTEM OF ENTERPRISE MANAGEMENT: INTERNATIONAL EXPERIENCE AND DOMESTIC PRACTICE
}

\author{
ДЕБІТОРСЬКА ЗАБОРГОВАНІСТЬ, ІІЇ МІСЦЕ І РОЛЬ \\ В СИСТЕМІ УПРАВЛІННЯ ПІДПРИЕМСТВОМ: \\ МІЖНАРОДНИЙ ДОСВІД ТА ВІТЧИЗНЯНА ПРАКТИКА
}

The article considers interpretation of definition of accounts receivable and analyzes the current state of process of its settlement. There was conducted analysis of essence of the definition as determined by different researchers, and the author's own interpretation of this concept has been suggested. Accounts receivable is defined as the obligation of a debtor to transfer property, perform work, provide services, and pay cash on a certain date. Accounts receivable have been classified in accordance with accounting models of various systems, taking into consideration experience of European and other countries. The author investigated systematic approach to determining the best aspects of organization of receivables accounting worldwide for their implementation in the activities of domestic enterprises, which will make it possible to ensure the proper functioning of accounting department. The suggestions herein would allow increase information support of accounting data regarding volume and expected decrease in receivables for the purposes of enterprise management.

Key words: accounts receivable, receivables, accounting models, classification.

В статье рассмотрена трактовка дефиниции «дебиторская задолженность», проанализировано современное состояние процесса ее погашения. Проведен анализ сущности дефиниции разными авторами, предложено собственное толкование этого понятия. Дебиторская задолженность - это обязательство должника по передачи имущества, выполнению работ, предоставлению услуг, уплате денежных средств на определенную дату. Представлена классификация дебиторской задолженности в соответствии с учетными моделями систем бухгалтерского учета с учетом опыта европейских стран мира. Исследован системный подход к определению наилучших аспектов организации учета дебиторской задолженности в странах мира для имплементации их в деятельности отечественных предприятий, который даст возможность обеспечить надлежащее функционирование бухгалтерии. Приведенные предложения позво- 
лят увеличить информационное обеспечение данных бухгалтерского учета относительно объемов и ожидаемого уменьшения дебиторской задолженности для достижения целей управления предприятием.

Ключевые слова: дебиторская задолженность, учетные модели бухгалтерского учета, классификация.

У статті розглянуто трактування дефініції «дебіторська заборгованість», проаналізовано сучасний стан процесу її погашення. Досліджено економічну сутність дебіторської заборгованості та ії виникнення в умовах сталого розвитку. Проведено аналіз сутності дефініції різними авторами, запропоновано власне тлумачення цього поняття. Дебіторська заборгованість - це зобов'язання боржника 3 передачі майна, виконання робіт, надання послуг, сплати грошових коштів на певну дату. Розглянуто класифікацію дебіторської заборгованості як основу фрормування інфрормаційного забезпечення управління на різних рівнях. Внаслідок вивчення варіантів класифікації заборгованості виявлено не досить їх глибоку деталізацію. Запропоновано класифікувати її за такими класифікаційними ознаками: 1) строк погашення (довгострокова та поточна); 2) своєчасність погашення (безнадійна дебіторська заборгованість, дебіторська заборгованість, строк якої не настав, дебіторська заборгованість, не сплачена в строк); 3) статті бухгалтерського балансу (за товари (роботи й послуги), за розрахунками з бюджетом, за розрахунками за виданими авансами, за розрахунками з нарахованих доходів, за розрахунками з внутрішніх розрахунків та інша поточна дебіторська заборгованість); 4) строк позивної давності (прострочена та непрострочена); 5) оцінка вартості (первинна та чиста реалізаційна); 6) види (операційна (товарна) та неопераційна (нетоварна)); 7) особливі види (витрати майбутніх періодів і відстрочені податкові активи); 8) фрорма погашення (монетарна та немонетарна); 9) контрагенти (вітчизняних дебіторів та іноземних дебіторів); 10) забезпеченість (забезпечена та незабезпечена). Представлено класифрікацію дебіторської заборгованості відповідно до облікових моделей систем бухгалтерського обліку (Британо-американська, Континентальна, Південно-Американська, країн Східної Європи, Ісламська та Інтернаціональна) з огляду на досвід європейських країн світу. Досліджено системний підхід до визначення найкращих аспектів організації обліку дебіторської заборгованості в країнах світу для імплементації їх в діяльності вітчизняних підприємств, що дасть можливість забезпечити належне функціонування бухгалтерії. Наведені пропозиції дадуть змогу збільшити інформаційне забезпечення даних бухгалтерського обліку щодо обсягів та очікуваного зменшення дебіторської заборгованості для досягнення цілей управління підприємством.

Ключові слова: дебіторська заборгованість, облікові моделі бухгалтерського обліку, класифікація.

Statement of the problem. Ukraine is a state with a market form of economic development, which provides a basis for functioning of the social-economic-ecological system of any modern developed country, and which is influenced by numerous factors, both from internal and external environment, especially in conditions of instability, globalization and military action

Integration of Ukraine into the global economic system implies the creation of a free trade zone which positively affects not only trade and economic relations between states, but also functioning of production, which acquires an opportunity to produce and export products to European and other markets.

For this reason, effective management of accounts receivable is an important financial leverage for accelerating a company's capital turnover. The regularity of obtaining and executing payments, creating a doubtful debts reserve, attraction and allocation of funds, ensures a proper financial balance of a firm. Active and effective debt management provides for additional profit, and rational management of it contributes to regularity of pace of the company's core business.

Analysis of recent researches and publications. The study of the subject matter, role and place of accounts receivable in the enterprise management system is given considerable attention in scientific works and researches of many domestic and foreign scientists, in particular, such as M.D. Bilyk, E.O. Ivanov, K.S. Surnina, V.V. Sopko, V.P. Zavgorodniy, O.A. Petryk, M.V. Kuzhelnyi, V.H. Linnyk, V.F. Palii, V.V. Pali, H.H. Kireytsev.

In the context of sustainable development, there is an increased scientific interest to the issue of efficient management of receivables, as well as the absence of a single integrated approach to its solution. Therefore, the question of determining and classifying of accounts receivable was, is and remains relevant, as the nature and range of operations are constantly expanding, new instruments are emerging in the market, and therefore information on financial situation provided to counterparties often hinders development of an enterprise. Therefore, management of receivables needs further research. All this determines the choice of the subject matter of the present scientific research, its goals and objectives, and also confirms its relevance and practical significance.

The purpose of the article is to provide a comprehensive study of theoretical positions, as well as to summarize foreign experience in arrangement of receivables accounting, and its imple- 
mentation in activities of domestic enterprises, which would provide an opportunity to ensure the proper functioning of accounting department.

Presentation of the main research material. As a result of unreasonable political events, inflationary processes, instability of public relations, the state of Ukraine's economy is deteriorating significantly, business activity of enterprises and their solvency are decreasing. Unsatisfactory state of corporate solvency is characterized by such signs as late repayment of accounts receivables or partial payment. This situation leads to emergence of negative events for an enterprise, such as doubtful and bad debts. Solution to this problem largely depends on improvement of organization of accounting of settlements with counterparties.

Economic development requires constant amendments to interpretation of definition of accounts receivable. Researches indicate that there is no unity of views among scientists about the concept of accounts receivable. The primary concept of the debtor (from the Latin debitum - debt - obligation) was identified not only with a person, but also with goods, money, and account [1].

Modern interpretation of concept of accounts receivable was investigated by $\mathrm{E}$. Desgrange and G. Dzappo, who considered one of its indicators characterizing financial state of an enterprise [2].

However, the scholars as F.F. Butinets, O.V. Lyshylenko and M.S. Pushkar noted that receivables refere to an amount of debtors' debts payable to a company on a certain date [3, p. 265; 4, p. 220; 5, p. 122].

According to Regulation (standard) of accounting 10 Accounts Receivable, the receivables mean "an amount of debtors' debts payable to a company on a certain date" [6].

However, modern scholars somehow do not converge in their views and therefore, in different ways, define and interpret the essence of receivables.

A critical review of contemporary domestic literature allowed the author to establish comprehensive approaches to definition of accounts receivable (table 1).

The above definitions indicate that different authors interpret definition of accounts receivable differently, but its essence does not change. Accounts receivable is generally defined as the amount of debt to an enterprise from other debtors, which is formed in the process of economic activity. Therefore, for the emergence of receivables, it is necessary for an enterprise to carry out business activities, as well as to make settlements with other enterprises or individuals.

Our analysis of definitions describing essence of accounts receivable concept in the special economic literature evidences that there is no single definition of it by various authors, as described in table 1.

In most papers by foreign scholars, interpretation of receivables (accounts receivable, sales volume or debtors) has the following translation terminology: accounts receivable, debtors' accounts, and debtor for settlements. As noted by D. Stone and K. Hitching, receivables is called accounts receivable, and debtors are persons who owe money for goods and services already received but not paid by them [25].

Professors of Harvard University Z. Bodi and R. Merton define accounts receivables as an amount that buyers of products have to pay to the company [26].

Foreign scholars (A. Velsh Hlen, H. Short Deniel) treat receivables as covering all claims of an enterprise to other legal entities or individuals in respect of money, goods or services [27].

In our opinion, the definition of accounts receivable by individual authors is incomplete, since the same subject is studied by them at different angles: through presentation of receivables only in the form of monetary assets; they characterize the debt as a sum of money received in a loan; the concept of debt is considered only from positon of creditor, and presence of the other party, which has its obligations, is omitted; they determine receivables as an investment of monetary assets into current assets or as funds in settlements, which does not completely disclose essence of the concept; there is no specified time factor that would affect the classification of receivables as a result.

On the basis of this research, the authors suggest their definition of receivables. Hence, accounts receivable is a debtor's obligation to transfer property, perform work, provide services, and pay cash on a certain date.

Accounting is determined by the environment in which it operates. Hence, the principles of accounting and financial reporting differ in various countries. The similarity of environment and presence of many common features predetermine emergence of a common accounting system.

The historical separation of countries and their national peculiarities predetermined development of different accounting approaches with their weak points, advantages and peculiarities. Hence, historically several organizational accounting models have been formed: British-American, Continental, South American, Eastern European, Islamic and International.

The authors suggest to consider the principles of emergence and formation of receivables on the basis on different (British-American, Continental and Islamic) organizational models.

The British-American model was developed in the UK and the USA. Significant contribution 
Determination of definition of accounts receivable in various sources of information

\begin{tabular}{|c|c|}
\hline Author/source & Interpretation of essence of accounts receivable \\
\hline $\begin{array}{l}\text { Regulation (standard) } \\
\text { of accounting } 10 \\
\text { Accounts Receivable }\end{array}$ & Amount of debtors' debts payable to a company on a certain date. \\
\hline $\begin{array}{l}\text { Regulation (standard) } \\
\text { of accounting } 13 \\
\text { Financial Instruments }\end{array}$ & $\begin{array}{l}\text { The amount arising from provision of funds, sale of other assets, work and services } \\
\text { directly to a debtor and is not a financial asset intended for resale. }\end{array}$ \\
\hline $\begin{array}{l}\text { Regulation (standard) } \\
\text { of accounting } 39 \\
\text { Financial Instruments: } \\
\text { recognition and } \\
\text { estimation }\end{array}$ & $\begin{array}{l}\text { These are derived financial assets with fixed payments that are identifiable and } \\
\text { have no quotes in the active market. }\end{array}$ \\
\hline $\begin{array}{l}\text { M.D. Bilyk, } \\
\text { E.O. Ivanov, } \\
\text { K.S. Surnina }\end{array}$ & $\begin{array}{l}\text { Considered economic essence of receivables, issues of analysis and internal } \\
\text { control, which can lead to improved management of receivables at an enterprise, } \\
\text { as well as property that is unpaid by counterparties or cash withdrawn from the } \\
\text { circulation of working capital. Suggested classification of debt on six grounds: } \\
\text { type of occurrence, maturity, security, counterparties, degree of compliance with } \\
\text { financial discipline, form of repayment. }\end{array}$ \\
\hline I.A. Blank & $\begin{array}{l}\text { Considered concept of accounts receivable as the sum of debts in favor of an } \\
\text { enterprise, as well as question of forming a policy for management of receivables. }\end{array}$ \\
\hline N.M. Novikova & $\begin{array}{l}\text { Offered accounting and management approaches to classification of accounts } \\
\text { receivable. }\end{array}$ \\
\hline S.F. Holov & $\begin{array}{l}\text { Accounts receivable is a financial asset that is a contractual right of one party to } \\
\text { receive money, and is consistent with corresponding obligation of other party to pay. }\end{array}$ \\
\hline H. Nashkerska & $\begin{array}{l}\text { Examined practical aspects of accounting of receivables and formation of doubtful } \\
\text { debts reserve. The method of classification of doubtful debts is expedient to use } \\
\text { by enterprises with a significant number of debtors, and vice versa - the method of } \\
\text { calculating the reserve based on solvency of each individual debtor is better to use } \\
\text { when the number of debtors is insignificant. }\end{array}$ \\
\hline $\begin{array}{l}\text { V.V. Sopko, } \\
\text { V.P. Zavgorodniy }\end{array}$ & $\begin{array}{l}\text { In order to organize accounts receivable, it was proposed to determine the objects } \\
\text { of debt by terms of repayment and to accumulate debt subjects by types of debt. } \\
\text { It is expedient to conduct analytical accounting for each type of indebtedness and } \\
\text { for each counterparty. }\end{array}$ \\
\hline $\begin{array}{l}\text { F.F. Butinets, } \\
\text { O.V. Oliynyk, } \\
\text { M.M. Shigun, } \\
\text { S.M. Shulepova }\end{array}$ & $\begin{array}{l}\text { Suggested to reflect in accounting policy such major aspects of organization of } \\
\text { accounting of receivables, as: criteria for grouping debts by terms of their occurrence } \\
\text { and repayment; method offorming a reserve of doubtful debts; schedule of documents } \\
\text { flow, confirming emergence of accounts receivable; accounting registers in which } \\
\text { receivables are recorded; procedure for the transfer of information from accounting } \\
\text { registers to the central accounting department and its display in accounting. }\end{array}$ \\
\hline N. Matytsyna & $\begin{array}{l}\text { Considered instruments of financial policy of accounts receivable management. } \\
\text { Defined its constituent elements, as well as factors influencing formation of } \\
\text { receivables, provided a list of primary documents, which may form basis for } \\
\text { reflection in accounting of various types of receivables. }\end{array}$ \\
\hline S.A. Kuznetsova & $\begin{array}{l}\text { Examined types and methods of assessing receivables. With a view to minimizing } \\
\text { deviations of estimated value of debt from its real value, proposed an integrated } \\
\text { approach to the assessment of accounts receivable, based on adjustment of initial } \\
\text { value of receivables in accordance with time coefficient. }\end{array}$ \\
\hline O.A. Petryk & $\begin{array}{l}\text { Considered peculiarities of reflection of contractual obligations and rights in } \\
\text { accounting. }\end{array}$ \\
\hline A.R. Leipi, I.D. Demina & $\begin{array}{l}\text { Considered weak points of analysis of turnover of receivables and proposed a } \\
\text { methodology for prospective analysis of accounts receivable. }\end{array}$ \\
\hline N.Yu. Zudina & $\begin{array}{l}\text { Offered different strategies for dealing with receivables: accounting strategy, } \\
\text { recovery strategy, and strategy of tracking possibility to recover debts. Examined } \\
\text { methods for monitoring and assessing reliability of debt. }\end{array}$ \\
\hline $\begin{array}{l}\text { M.V. Kuzhelnyi, } \\
\text { V.H. Linnyk }\end{array}$ & Debt repayment rights. \\
\hline V.F. Palii, V.V. Palii & Investments in working capital. \\
\hline H.H. Kireytsev & $\begin{array}{l}\text { Accounts receivable is a component of working capital, which is a set of requirements } \\
\text { to individuals or legal entities for payment for goods, products, services. }\end{array}$ \\
\hline O.M. Petrov & Considered method of a comprehensive analysis of accounts receivable. \\
\hline
\end{tabular}


to the development of this model belongs to the Netherlands. The main purpose of the model is: development and targeting of accounting for information requests of stakeholders. Since the owners of companies departed from operational management and transferred their powers to management personnel, then financial accounting information became the main source showing the company's position on the market in order to control efficient use of resources. Characteristic features of this model are:

- stable political system of the country;

- well-developed economy;

- rules (standards) of conducting business are approved by professional organizations and institutions;

- financial statements are aimed at meeting the needs of stakeholders.

However, in addition to the advantages, there are some weaknesses: the lack of unified Accounts Charts, accounting registers and reporting forms.

Ukraine, Austria, Italy, France, Germany, Japan belong to the Continental model. It involves a close relationship between business and financial institutions, which largely satisfy the needs of financial companies. Focus on managerial inquiries of stakeholders is not a priority of accounting. On contrary, accounting policy is aimed at satisfying requirements of the government. In particular, governments of these countries require the publication of information about company in open information domain. The main features of this model are:

- stable political system;

- well-developed economy;

- financial statements are aimed at satisfying the needs of a bank;

- accounting registers are regulated by law and accounting policies are aimed at meeting needs of the government for compiling and analyzing macroeconomic indicators.

The South American model is characterized by a high rate of inflation. Accounting and reporting are focused on needs of state authorities. Financial information provided in the registers is fairly uniformed.

It is fully focused on financial reporting to meet needs of tax authorities. Such a procedure for accounting and compiling financial statements significantly simplifies accounting and increases efficiency of government agencies. Consequently, the main characteristics of this model are:

- unstable political system;

- undeveloped economy;

- financial statements are aimed at satisfying needs of government agencies;

- rules of accounting (standards) are regulated by law;
- accounting policy is aimed at meeting needs of state agencies.

The Islamic model of accounting is one of the alternative directions of accounting development in a globalizing environment. It is assigned to solve a number of major socio-economic issues, such as:

- increase of social protection of society;

- overcoming poverty and unemployment;

- increase of social state standards;

- increase of economic safety of a country, and solution of social-economic-ecological problems.

The main precondition for emergence of the model is activation of processes of ethnic and confessional self-identification, which are related to social and intellectual development of the Muslim world. This model is characterized by a number of features:

- property of business persons for the purpose of paying Zakat (tax on property and income of Muslims, which is obligatory under Sharia Law) is estimated at market value and classified according to its rate;

- the main form of reporting is balance sheet which indicates all the property belonging to an enterprise;

- sources of entity's property are related to implementation of Islamic financial instruments. This is related to prohibition of accrual and payment of interest - Riba (prohibition of loan interest);

- observance of the basic economic principles that allow to carry out economic and financial operations in accordance with developed financial instruments;

- the financial results of business persons are determined in accordance with distribution of profit and satisfaction of social needs, for this purpose, the Value Added Report is drawn up;

- the main emphasis is on the fact that only the Islamic model of the economy can provide a real balance between material and spiritual aspects in society.

In the interests of multinational corporations and foreign participants of international currency markets, there is a need for consistency in international accounting. Thereby, an International model has emerged. Financial statements of large corporations have to comply with International Accounting Standards.

In practice of foreign countries, the presentation of accounts receivable significantly differs from national standards. In the IFRS system (IFRS 1 First-time Adoption of International Financial Reporting Standards, IFRS 32 Financial Instruments: Presentation, IFRS 39 Financial Instruments: Recognition and Measurement) classifi- 
cation, as well as recognition are not explicitly indicated [28]. Classification of accounts receivable is advisory, not prescriptive.

Since accounts receivable occupy a dominant position in the structure of working capital of an enterprise, its accounting affects results of economic activities and disclosure of information about financial state.

Classification of receivables in different accounting models has its own characteristics. Thus, IFRS classification of accounts receivable involves only one limitation "within one year". According to the rest of the models, the expected maturity of receivables is specified in contracts and is divided into current and non-current debts.
The latter, in some countries, for example, the $U A E$, is divided into medium and long-term. Accounts receivable in the balance sheet of a foreign company, in particular in the countries of the British-American accounting system, are classified as follows:

- accounts receivable is type of receivables that exists as a result of providing a short-term loan, the so-called open account by seller to buyer. Under normal circumstances, funds on this account must be settled within 30-60 days;

- promissory notes receivable;

- receivables not related to sale.

The Estonian balance sheet shows receivables as follows:

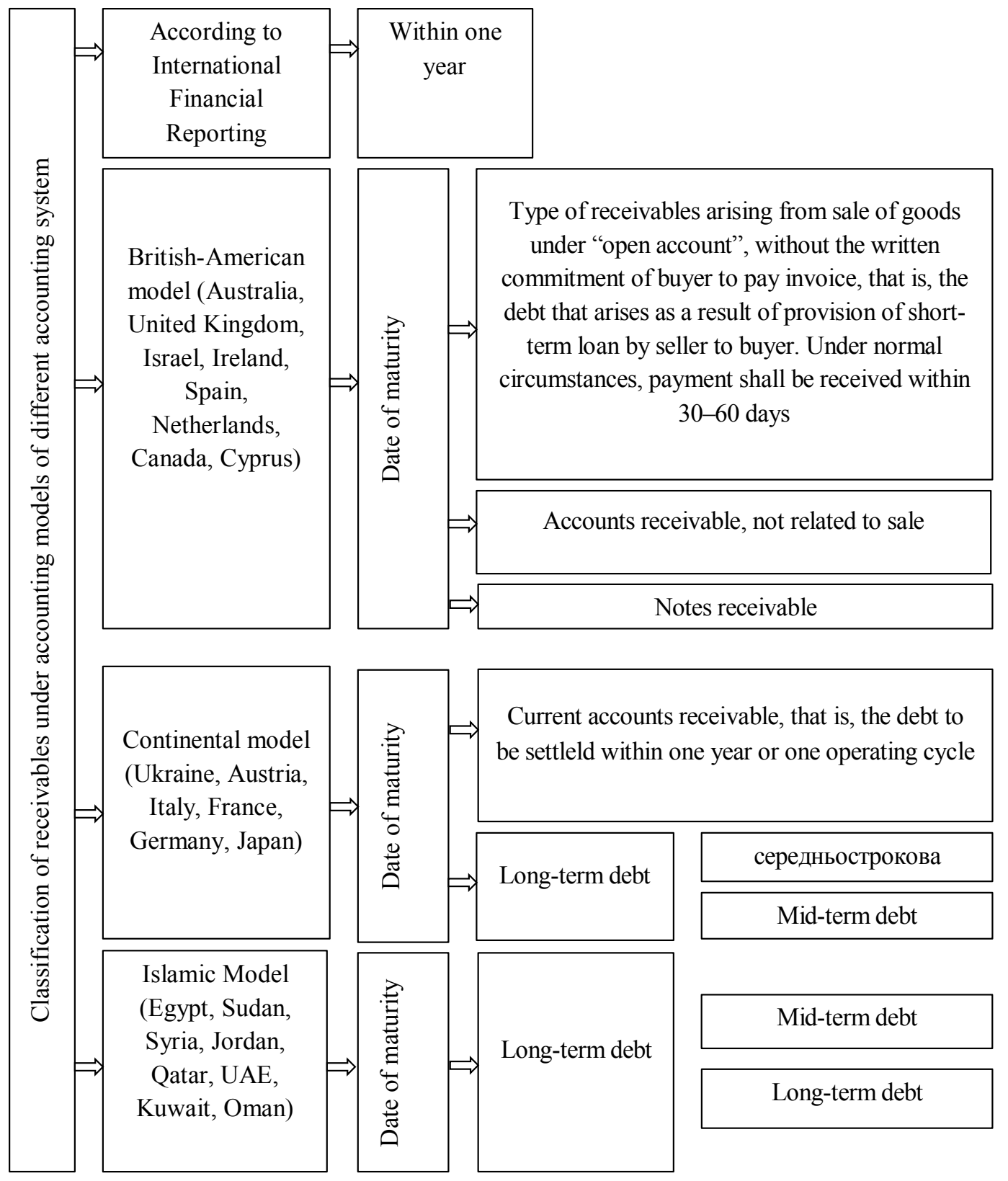

Fig. 1 Classification of receivables under models of the accounting systems Source: systematized by the author under source [29] 
- receivables from subsidiaries and parent companies;

- receivables from related companies;

- settlements with shareholders;

- other short-term receivables

Classification of accounts receivable in the context of accounting models is presented in fig. 1.

Thus, in general terms, under expected maturities that are set forth in contracts, in all countries, debts are divided into a current accounts receivable (which should be settled within one year or operating cycle) and long-term debts. For example, in Ukraine and the USA, there are bad and doubtful accounts receivable. In the UAE and other countries Islamic accounting model, receivables are divided into medium and long-term.

The classification of debt in relation to the presentation in financial statements of a company is unique in different countries. In Ukraine, receivables under the above-mentioned classification are divided into: receivables for goods, works and services and other receivables.

In the USA, the UAE and other countries of Islamic accounting model, the classification of debt as reflected in companies' statements, in a similar way. In these countries, the following is distinguished: accounts receivable, promissory notes receivable and receivables not related to sale. In Estonia, the classification of debt as reflected in companies' statements, is as follows: accounts receivable, receivables not related to sale, accounts receivable of subsidiaries and parent companies.

Studies evidence that current classification of debt is incomplete and covers only one characteristic. The authors deem that receivables should be classified as follows: 1) maturity: long-term and current; 2) timeliness of settlement: bad accounts receivable, receivables the repayment term of which did not come, and receivables not settled in due time; 3) items of balance sheet: settlements for goods (work and services), settlements with budget, settlement under issued advances, settlements from accrued income, settlements from internal settlements and other current receivables; 4) the term of prescription: overdue and non-overdue; 5) valuation: primary and net realization; 6) types: operational (commodity) and non-operational (non-commodity); 7) special types: expenses of future periods and deferred tax assets; 8) form of settlement: monetary and non-monetary; 9) contractors: domestic debtors and foreign debtors; 10) security: secured and unsecured.

Conclusions from the study. In view of the results obtained in the course of research, there was conducted analysis of accounts receivable under various definitions. Most of the above definitions were partial and required supplements since they did not disclose the nature of accounts receivable, or the researchers considered it from a certain point of view. The authors' own interpretation of receivables was proposed, namely: receivables are obligation of a debtor on the transfer of property, performance of work, provision of services, and payment of monetary funds on a certain date.

For the organization of accounting and analysis of settlements with counterparties, the classification of receivables is important. Thus, correct classification and proper classification criteria of the receivable provide for order of its accounting and effectiveness of management, and, above all, adoption of managerial decisions in order to obtain maximum profit.

\section{References:}

1. Nashkerska H. (2019) Osoblyvosti vyznannia ta otsinky potochnoi debitorskoi zaborhovanosti za produktsiiu, roboty i posluhy [Features of recognition and assessment of current receivables for products, works and services] - Bukhhalterskyi oblik i audyt - Accounting and auditing, 11, p. 31-37 [in Ukrainian].

2. Bilyk M.D. Upravlinnia debitorskoiu zaborhovanistiu pidpryiemstv [Debt management of enterprises]. Financy Ukrainy [Finance of Ukraine]. 12/2003, 12, p. 24-36 [in Ukrainian].

3. Butynets F.F. (Eds.) (2003) Bukhhalterskyi finansovyi oblik: pidruchnyk, 5te vydannia, dopovnene $i$ pereroblene [Financial Accounting: Manual, 5th edition, edition, extended and revised]. Zhytomyr : PP “Ruta”, 726 p. [in Ukrainian].

4. Lyshylenko O.V. (2003) Bukhhalterskyi finansovyi oblik: navchalnyi posibnyk [Financial Accounting: Manual]. Kyiv : Tsentr navchalnoi literatury, 524 p. [in Ukrainian].

5. Pushkar M.S. (2002) Finansovyi oblik: Pidruchnyk [Financial Accounting: Manual]. Ternopil : KartBlansh, 628 p. [in Ukrainian].

6. Debitorska zaborhovanist: Polozhennia (standart) bukhgalterskogo obliku 10 [Regulation (standard) of accounting 10 Accounts Receivable], approved by the Ministry of Finance of Ukraine as of 08.10.99, No. 237. (2001) Bukhhalterskyi oblik - Accounting, 52/2 (467), 55-56 [in Ukrainian].

7. Finansovi instrumenty: Polozhennia (standart) bukhgalterskogo obliku 13 [Regulation (standard) of accounting 13 Financial Instruments], approved by the Ministry of Finance of Ukraine as of 30.11.2001, No. 559. (n.d.) Retrieved from: http://zakon.rada.gov.ua. 
8. Finansovi instrumenty: vyznannia ta otsinka: Mizhnarodnyi Standart Finansovoi Zvitnosti 39 [Financial Instruments: recognition and estimation: International Financial Reporting Standard 39], (n.d.) Retrieved from: http://zakon.rada.gov.ua.

9. Ivanov E.O. (2005) Klasyfikatsiia faktoriv, shcho vplyvaiut na zahalnyi riven debitorskoi zaborhovanosti pidpryiemstva [Classification of factors influencing the general level of receivables of the enterprise]. Visnyk MSU - Annals of MSU, 1-2. T.VIII. Harkov, p. 35-38 [in Ukrainian].

10. Surnina K.S. (2002) Udoskonalennia obliku debitorskoi i kredytorskoi zaborhovanosti promyslovykh pidpryiemstv [Improvement of accounts receivable and accounts payable of industrial enterprises] Extended abstract of candidate's thesis. Lugansk, p. 19 [in Ukrainian].

11. Blank I.A. (2008) Osnovy finansovogo menedzhmenta. Pidruchnyk [Basics of financial Management. Manual]. Kyiv : Elga, p. 724 [in Ukrainian].

12. Novikova N.M. (2005) Metodychni pidkhody do klasyfikatsii debitorskoi zaborhovanosti pidpryiemstva [Methodological approaches to the classification of receivables of enterprise]. Visnyk Lvivskoi derzhavnoi finansovoi akademii. Ekonomichni nauky - Annals of the Lviv State Financial Academy. Economic Sciences, 9, Lviv, p. 203-211 [in Ukrainian].

13. Holov S.F., Kosiushenko V.M. (2001) Bukhhalterskyi oblik za mizhnarodnymy standartamy: pryklady ta komentarii: praktychnyi posibnyk. [Accounting for international standards: examples and comments: practice manual], Kyiv : Libra, 670 p. [in Ukrainian].

14. Sopko V.V., Zavhorodniy V.P. (2004) Orhanizatsiia bukhhalterskoho obliku, ekonomichnoho kontroliu ta analizu. Pidruchnyk [Accounting organization, economic monitoring and analysis. Manual]. Kyiv : KNEU, 411 p. [in Ukrainian].

15. Butynets F.F., Oliinyk O.V., Shyhun M.M., Shulepova S.M. (2001) Orhanizatsiia bukhhalterskoho obliku: navchalnyi posibnyk. [Organizationof Financial Accounting: manual]. Zhytomyr : PP "Ruta", 576 p. [in Ukrainian].

16. Matytsyna, N.O. (2015) Osnovni zasady rehuliuvannia rozrakhunkovykh vidnosyn cherez upravlinnia debitorskoiu zaborhovanistiu [Basic principles of regulation of settlement relations through management of accounts receivable] - Bukhhalterskyi oblik $i$ audyt - Accounting and auditing, 12, p. 38-42 [in Ukrainian].

17. Kuznetsova S.A. (2014) Perspektyva bukhhalterskoho obliku: stratehichnist, elektronna komertsiia ta sotsialna spriamovanist [Prospect of accounting: strategic, e-commerce and social orientation]. Evropeiskyi vektor ekonomichnoho rozvytku. Ekonomichni nauky - European vector of economic development. Economic Sciences, 1, p. 73-83. Retrieved from: http://nbuv.gov.ua/UJRN/ever_2014 [in Ukrainian].

18. Petryk O.A., Zotov V.O., Riadska V.V., Chumakova I.Yu. et al. (2015) Audut: pidruchnyk [Audit: manual]. O.A. Petryk (Ed). Kyiv : KNEU, 504 p. [in Ukrainian].

19. Leipy A.R., Demyna I.D. (2010) Modelirovanie zavisimosti obrazovania debitorskoi zadolzhennosti ot istochnikov finansirovania. [Modeling the dependence of the formation of receivables from sources of financing: Economic analysis: theory and practice.]. Ekonomycheskii analiz: teoria i praktika Economic analysis: theory and practice, 41, p. 18-23 [in Russian].

20. Zudina N.Yu. (2009) Analiz i regulirovanie debitorskoi zadolzhennosti v kommercheskoi organizatsyyii [Analysis and regulation of receivables in a commercial organization]. Extended abstract of candidate's thesis. Moscow : FGOU, 26 p. [in Russian].

21. Kuzhelnyi M.V., Linnyk V.H. (2001), Teoriia bukhhalterskoho obliku [Theory of Accounting]. Kyiv : KNEU, 334 p. [in Ukrainian].

22. Palii V.F., Palii V.V. (1998) Finansovyi uchet: Uchebnoe Posobie v 2 h chastiakh [Financial accounting: Study Manual in two volumes]. (Vol. 1). Moscow : FBK-Press Publ., 304 p. [in Russian].

23. Kireytsev H.H. (2002), Finansova zvitnist pidpryiemstv ta ii analiz [Financial reporting of enterprises and its analysis]. Kyiv : Tsentr uchbovoi literatury, 452 p. [in Ukrainian].

24. Petrov A.M. (2007) Problemy sovremennoi ekonomiky [Problems of the modern economy]. Evraziiskii mezhdunarodnyi nauchno-analiticheskii zhurnal - Eurasian International Scientific Analytical Journal, 1 (21). Retrieved from: http://www.meconomy.ru/art.php?nArtld=1295\#ftn1 [in Russian].

25. Stone D., Hitching, K. (1998), Bukhhalterskyi oblik ta finansovyi analiz [Accounting and financial analysis], (Y.A. Ohybyn, G.Y. Ohybyn, Trans). Moscow : Sirin, 302 p. [in Ukrainian].

26. Body Z., Merton R. (2000), Finansy [Finance], Moscow : Izdatelskii dom “Viliams”, 592 p. [in Russian].

27. Velsh H.A., Short D.H. (1999). Osnovy finansovoho obliku [Fundamentals of financial accounting]. (O. Minin, O. Tkach, Trans). Kyiv : Osnovy, 943 p. [in Ukrainian].

28. Mizhnarodni Standarty Finansovoi Zvitnosti: Nakaz Ministerstva Finansiv Ukrainy [International Financial Reporting Standards: Decree by the Ministry of Finance of Ukraine]. (2016). www.minfin. gov.ua. Retrieved from: https://www.minfin.gov.ua/news/view/mizhnarodni-standarty-finansovoizvitnosti [in Ukrainian].

29. Butynets F.F., Horetska L.L. (2002). Bukhhalterskyi oblik u zarubizhnykh krainakh. Navchalnyi posibnyk dlia studentiv vyshchykh navchalnykh zakladav spetsialnosti 7.050106 "Oblik $i$ audit" [Accounting in foreign countries. A manual for students of higher education in the qualification 7.050106 "Accounting and Audit"]. Zhytomyr : PP “Ruta", 544 p. [in Ukrainian]. 